\title{
Physiological measurements of coffee young plants coexisting with sourgrass
}

\author{
Leonardo Bianco de Carvalho ${ }^{1^{*}}$ and Pedro Luis da Costa Aguiar Alves ${ }^{2}$ \\ ${ }^{1}$ Professor at Centre of AgriVeterinarian Sciences of the Santa Catarina State University, Lages, Brazil, Ibcarvalho@cav.udesc.br. ${ }^{2}$ Professor at \\ Faculty of Agrarian and Veterinarian Sciences of the Sao Paulo State University, Jaboticabal, Brazil, plalves@fcav.unesp.br \\ ${ }^{*}$ Author for correspondence
}

\begin{abstract}
Coffee is an important crop planted in Brazil and commonly infested by sourgrass plants. Crescent densities of sourgrass growing with coffee young plants were maintained up to weed full flowering when physiological measurements were performed in the crop to evaluate photosynthetic coffee plant responses to increasing of weed competition. Experiments were arranged in a completely randomized design with seven replicates. The concentration of $\mathrm{CO}_{2}$ within the leaf, the leaf transpiration, the stomatal conductance, the $\mathrm{CO}_{2}$ assimilation rate, and the ratio $\mathrm{Fv} / \mathrm{Fm}$ of coffee plants were not affected by increasing of sourgrass density. On the other hand, relative content of total chlorophyll was reduced by $13.9 \%$ in the density of 8 sourgrass plants. Gas exchange and fluorescence of chlorophyll of young coffee plants were not dependent on increasing of the intensity of competition while an opposite response occurred for chlorophyll content.
\end{abstract}

Keywords: Coffea arabica, Digitaria insularis, competition, gas exchange, chlorophyll fluorescence, additive experiment.

\section{Introduction}

Coffee is one of the world's most popular beverages (Fujioka and Shibamoto 2008). It is also the most important traded commodity in the world after oil (Naidu et al. 2008). Among coffee tree species, Coffea arabica L. shows the highest economic importance, producing the consumers' most appreciated coffee drink (Nascimento et al. 2006). In Brazil, coffee production is of economic as well as social importance; this country is the main world producer (Marana et al. 2008), where Minas Gerais State is responsible for $50 \%$ of the total Brazilian coffee production, also showing the most qualified coffee industry (Silva et al. 2007).

Young coffee plants are very sensible to weed interference after being planted in the fields due to its low initial growth (Silva and Ronchi 2003, Lemes et al. 2010). Weeds may constrain crops directly by competition, allelopathy and harvest impediment, or indirectly by pests and pathogens hosting (Radosevich et al. 1997), causing quantitative and qualitative losses to agriculture products, such that these plants may be troublesome to coffee producers due to the interference on the tree growth and development, and on fruits yield (Dias et al. 2008, Marcolini et al. 2009). In coffee plantations, weeds may also affect the macronutrients uptake (Ronchi et al. 2007) and they can be alternative hosts of coffee strains of Xylella fastidiosa which causes coffee leaf scorch (CLS), a serious disease of $C$. arabica (Lopes et al. 2003).

Weed competition probably is the most important factor influencing crop growth by reducing availability of nutrients, water, space, light and $\mathrm{CO}_{2}$ (Radosevich et al. 1997). In this research, we supposed that Digitaria insularis plants, an important weed in coffee plantations in Brazil commonly known as sourgrass, could affect coffee photosynthesis due to crescent increasing of the intensity of competition. The most commonly methodology used to estimate the intensity of weed competition on crops is the additive experiment. In that experiment, crop density is maintained constant while weed density is increased so that crop is used as a comparative indicator for weed competitiveness and aggressiveness (Jolliffe et al. 1984, Cousens 1991, Radosevich et al. 1997).

The objective of this research was to evaluate physiological coffee plant responses, related to photosynthetic measurements, growing in coexistence with crescent densities of sourgrass plants.

\section{Material and methods}

Plant material and growing conditions. Young plants of C. arabica cultivar Catuaí Vermelho IAC-144 with four pairs of leaves and sourgrass seedlings with four fullexpanded leaves were used in this study. Plants of both species were transplanted to mesocosms $(0.75 \mathrm{~m}$ width and $1.50 \mathrm{~m}$ depth) (Figure 1) buried in the ground, in Jaboticabal, Brazil, located at 21015'22"S and 481' $58^{\prime \prime}$ W. Mesocosms were filled with Oxisol clay textured substrate. A week before transplanting, two liters of manure per mesocosm were incorporated to substrate in $10 \mathrm{~cm}$ depth as well as NPK fertilizer was supplied at $80 \mathrm{~g}$ per mesocosms in the time of transplanting. Pesticides were applied preventively once in a fortnight. Water was daily supplied, exceptionally in rainy days.

Experimental design and treatments. Treatments consisted of the coexistence of crescent densities (1, $2,4,8$ and 16 plants) of sourgrass with one coffee plant, in each mesocosm, up to the full flowering of the weed species (108 days after transplanting - DAT). A weed-free check was also maintained. Treatments were arranged in a completely randomized design with seven replicates.

Gas exchange and chlorophyll fluorescence measurements. The concentration of $\mathrm{CO}_{2}$ within the leaf (Ci), the leaf transpiration $(\mathrm{E})$, the stomatal 
conductance (gs) and the $\mathrm{CO}_{2}$ assimilation rate $(\mathrm{A})$ were evaluated using an infra-red gas analyzer - IRGA (Li-Cor, LI6400, USA) calibrated at $522 \mu \mathrm{mol} \mathrm{m}^{-2} \mathrm{~s}^{-1}$ of photosynthetically active radiation. The ratio $\mathrm{Fv} / \mathrm{Fm}$ (variable fluorescence/maximum fluorescence) was obtained using a fluorometer (Hansatech, PEA-MK2, United Kingdom). Measurements were performed in both leaves of the third pair of full-expanded leaves, in a sunny day, without clouds, from $8 \mathrm{~h} 00$ am to $10 \mathrm{~h} 00$ am, at 108 DAT.

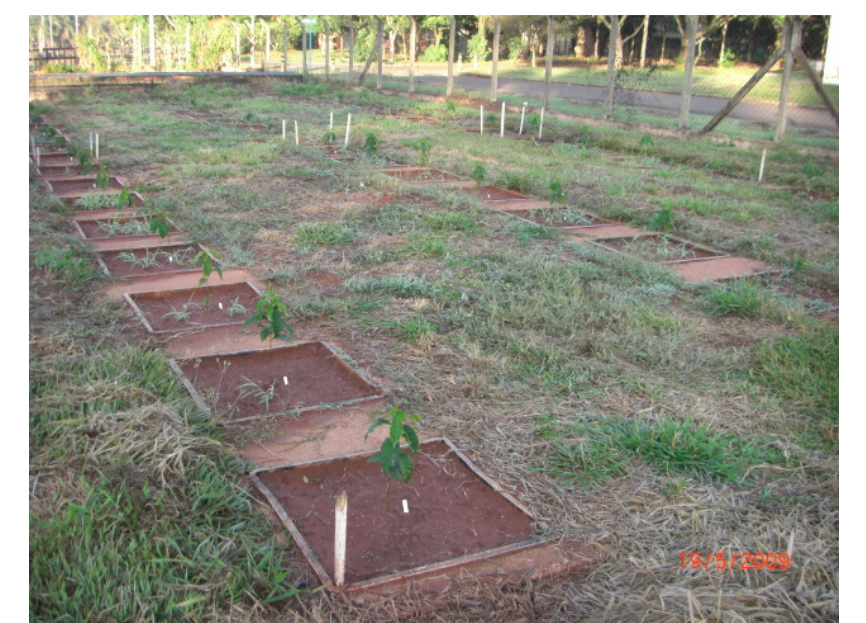

Figure 1. General overview of the experimental area. Jaboticabal, Brazil, 2009 .

Chlorophyll content measurements. The relative content of total chlorophyll was estimated using a chlorophylometer (Minolta, SPAD-502, Japan), at 108 DAT. Four measurements were performed in the same leaves and the same conditions as gas exchange and fluorescence measurements.

Plant dry mass accumulation. Both sourgrass and coffee plants were cut off close to the ground and dried in an air convection oven at $70{ }^{\circ} \mathrm{C}$ for $96 \mathrm{~h}$. Following, dried material was weighted using an analytical balance (Marte, AS2000C, Brazil) for dry mass determination.

Statistical analysis. Two Experiments were carried out during 2009 and 2010, so that, in each experiment, mean data of measurements were calculated for each treatment and expressed as a percentage of the weedfree check. After that, a previous ANOVA $(P>0.05)$ was performed to exclude the effect of the interaction between treatments and experimental repetitions. So, mean data between the experimental repetitions were calculated for each treatment and then submitted to ANOVA to detect differences among the treatments. Tukey test was also performed when ANOVA was significant. ANOVA and Tukey tests were performed at $5 \%$ of probability, using Statistica software (StatSoft, version 8.0, USA).

\section{Results and discussion}

Higher sourgrass dry mass accumulation was observed when weed density increased, mainly after a density of 4 plants per mesocosm, comparing to the dry mass of 1 sourgrass plant (Table 1). This fact indicates that the intensity of weed competition increased in the highest weed densities (Radosevich et al. 1997). On the other hand, coffee dry mass accumulation decreases when weed density increases as a consequence of the augmenting of the intensity of weed competition.

Table 1. Dry mass accumulation of Digitaria insularis and Coffea arabica plants at 108 days after growing together from the transplanting. Jaboticabal, Brazil, 2009-2010.

\begin{tabular}{ccc}
\hline $\left.\begin{array}{c}\text { Weed Density } \\
(\text { plant mesocosm }\end{array}{ }^{-1}\right)$ & $\begin{array}{c}\text { Weed Dry Mass } \\
\left(\mathrm{g} \mathrm{mesocosm}^{-1}\right)\end{array}$ & $\begin{array}{c}\text { Coffee Dry Mass } \\
\left(\mathrm{g} \mathrm{plant}^{-1}\right)\end{array}$ \\
\hline 0 & - & $100.0 \pm 11.1 \mathrm{~A}$ \\
1 & $100.0 \pm 9.2 \mathrm{C}$ & $78.7 \pm 16.0 \mathrm{AB}$ \\
2 & $149.3 \pm 12.8 \mathrm{C}$ & $74.7 \pm 6.8 \mathrm{~B}$ \\
4 & $238.8 \pm 10.6 \mathrm{~B}$ & $70.8 \pm 8.5 \mathrm{~B}$ \\
8 & $315.7 \pm 6.4 \mathrm{AB}$ & $67.5 \pm 9.7 \mathrm{~B}$ \\
16 & $395.4 \pm 6.9 \mathrm{~A}$ & $58.4 \pm 11.1 \mathrm{~B}$ \\
\hline F & $133,47^{* *}$ & $2.74^{\star}$ \\
CV (\%) & 22,91 & 31.77 \\
\hline
\end{tabular}

The concentration of $\mathrm{CO}_{2}$ within the leaf, the leaf transpiration, the stomatal conductance, the $\mathrm{CO}_{2}$ assimilation rate, and the ratio $\mathrm{Fv} / \mathrm{Fm}$ of coffee plants were not reduced when crop had grown coexisting with crescent densities of sourgrass plants (Table 2). On the other hand, relative content of total chlorophyll decreased due to interference of sourgrass plants in densities of 8 and 16 plants per mesocosm, being different of the weed-free check. Thus, it is possible to speculate that photosynthetic rate of coffee plants was not influenced by coexisting with sourgrass up to 16 plants per mesocosm. However, this coexistence probably provided a reduction of environmental resources allocation by coffee plants, decreasing the synthesis of chlorophyll molecules.

Results for gas exchange of rice plants indicated that photosynthetic rate decreases when intensity of competition increases (Concenço et al. 2011). It occurred due to a smaller $\mathrm{CO}_{2}$ use, affected by stomatal opening that is influenced by light (Nishio et al. 1984), more specifically, the light quality (Merotto Júnior et al. 2009). Sharkey and Raschke (1981) and Floss (2008) reported that stomatal opening is less dependent on the $\mathrm{CO}_{2}$ concentration in the leaf, responding directly by light. In this sense, under competition and shading, light balance participates in stomatal opening and gas balance between the internal part of the leaf and the external environment (Loreto and Bongi 1989). However, we believe that this theory is true only for sun plants.

Coffee species are naturally shade plants (Jha and Dick 2010) and we found that gas exchange was not dependent on the intensity of competition. We can also emphasize that gas exchange was not dependent on shading because coffee plants were totally shaded by sourgrass plants when gas exchange measurements were performed (Figure 2). So, shading was not a factor of interference on gas exchange for coffee plants as well as the intensity of weed competition.

We also have in mind that the fact of supplying water periodically can influence on coffee gas exchange due to the reduction of the intensity of weed competition for this environmental resource. Water 
Table 2. Physiological measurements of Coffea arabia plants coexisting with crescent densities of Digitaria insularis, at 108 days after transplanting. Jaboticabal, Brazil, 2009-2010.

\begin{tabular}{ccccccc}
$\begin{array}{c}\text { Weed Density } \\
\left(\text { plant mesoc }{ }^{-1}\right)\end{array}$ & $\begin{array}{c}\mathrm{ci} \\
\left(\mu \mathrm{mol} \mathrm{CO} \mathrm{m}^{-2}\right)\end{array}$ & $\begin{array}{c}\mathrm{E} \\
\left(\mathrm{mmol} \mathrm{H}_{2} \mathrm{O} \mathrm{m}^{-2} \mathrm{~s}^{-1}\right)\end{array}$ & $\begin{array}{c}\mathrm{gs} \\
\left(\mathrm{mol} \mathrm{H}_{2} \mathrm{O} \mathrm{m}^{-2} \mathrm{~s}^{-1}\right)\end{array}$ & $\begin{array}{c}\mathrm{A} \\
\left(\mu \mathrm{mol} \mathrm{CO} \mathrm{m}^{-2} \mathrm{~s}^{-1}\right)\end{array}$ & $\begin{array}{c}\text { Chlorophyll } \\
(\mathrm{UR})\end{array}$ \\
\hline 0 & $100.0 \pm 3.0$ & $100.0 \pm 10.9$ & $100.0 \pm 8.4$ & $100.0 \pm 7.2$ & $100.0 \pm 2.8$ & $100.0 \pm 0.9 \mathrm{~A}$ \\
1 & $100.6 \pm 3.1$ & $98.6 \pm 5.5$ & $101.8 \pm 9.5$ & $99.5 \pm 7.1$ & $99.4 \pm 2.5$ & $95.7 \pm 2.4 \mathrm{AB}$ \\
2 & $100.4 \pm 4.7$ & $94.6 \pm 12.2$ & $100.9 \pm 7.3$ & $95.9 \pm 8.9$ & $100.4 \pm 3.2$ & $93.2 \pm 2.2 \mathrm{ABC}$ \\
4 & $99.9 \pm 2.5$ & $107.5 \pm 5.1$ & $98.6 \pm 10.0$ & $105.9 \pm 4.8$ & $102.5 \pm 3.0$ & $90.9 \pm 1.2 \mathrm{ABC}$ \\
8 & $102.0 \pm 3.2$ & $112.9 \pm 7.2$ & $103.5 \pm 9.7$ & $104.4 \pm 4.3$ & $103.4 \pm 4.5$ & $86.1 \pm 1.4 \mathrm{BC}$ \\
16 & $102.9 \pm 2.0$ & $104.1 \pm 4.6$ & $102.6 \pm 9.1$ & $100.3 \pm 6.3$ & $103.8 \pm 2.7$ & $84.4 \pm 2.0 \mathrm{C}$ \\
\hline $\mathrm{F}$ & $0.98^{\mathrm{NS}}$ & $0.62^{\mathrm{NS}}$ & $0.25^{\mathrm{NS}}$ & $0.47^{\mathrm{NS}}$ & $0.55^{\mathrm{NS}}$ & $12.18^{*}$ \\
$\mathrm{CV}(\%)$ & 22.98 & 21.47 & 24.71 & 17.28 & 7.48 & 4.83 \\
\hline
\end{tabular}

availability influences on stomatal opening that, in this way, affects gas exchange. Stomatal conductance is responsible by $\mathrm{CO}_{2}$ flux balance between the internal part of the leaf and the external environment, so that less stomatal opening provides high stomatal resistance and, in consequence, transpiration decreases (Taiz and Zeiger 2006). So, coffee stomatal opening was not influenced by coexisting with sourgrass and, in consequence, gas exchange was also not affected.

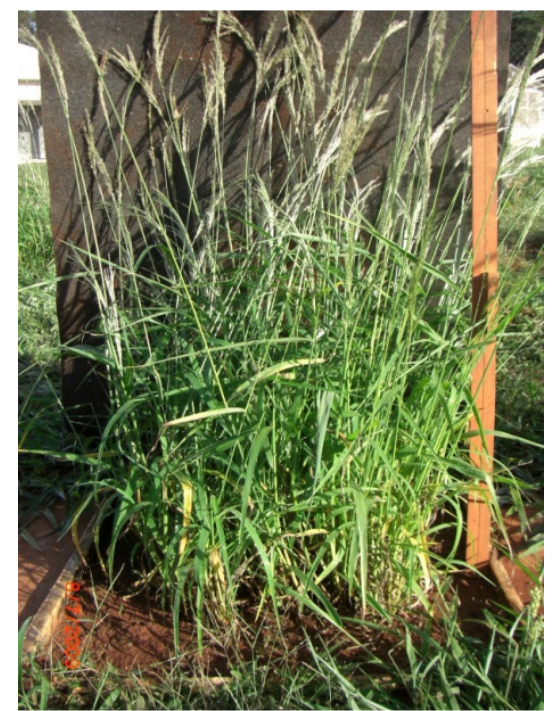

Figure 2. Image of a Coffea arabica plant under coexistence with sourgrass plants in a density of 16 plants per mesocosm, at 108 days after transplanting. Jaboticabal, Brazil, 2009.

Chlorophylls are the main photosynthetic pigments found within the chloroplasts whose synthesis is directly dependent on some nutrients such as magnesium, iron and manganese (Taiz and Zeiger 2006). So, coexistence with weeds can provided a high competition for environmental resources so that weeds can uptake and immobilized nutrients that could not be allocated by crops (Radosevich et al. 1997), reducing chlorophyll synthesis.

Finally, we have to point out that coffee plants as well as other shade plants can reduce gas exchange under a more critical intensity of competition or/and shading. So, other studies are needed to evaluate photosynthetic measurements of coffee plants growing in coexistence with sourgrass or other weeds to elucidate the novel of weed competition on crop net photosynthesys.

\section{Conclusions}

Gas exchange and fluorescence of chlorophyll of young coffee plants are not affected by coexisting with sourgrass up to the full flowering of the weed species. On the other hand, chlorophyll content of coffee plants is reduced due to interference of sourgrass.

\section{Acknowledgements}

This research is a part of the Thesis of Doctorate of the first author supported by Brazilian CNPq Doctorate Scholarship project 201417/2009-0.

\section{References}

Concenço G, Aspiazú I, Galon L, Ferreira EA, Freitas MAM, Fialho CMT, Schwanke AML, Ferreira FA, Silva AA. 2011. Photosynthetic characteristics of hybrid and conventional rice plants as a function of plant competition. Planta Daninha 29:803-809.

Cousens R. 1991. Aspects of the design and interpretation of competition (interference) experiments. Weed Technol 5:664-673.

Dias TCS, Alves PLCA, Lemes LN. 2008. Effects of the width of weed control strips on coffee plant performance. Científica 36:81-85.

Floss EL. 2008. Crop physiology. Passo Fundo: UPF. $733 p$.

Fujioka K, Shibamoto T. 2008. Chlorogenic acid and caffeine contents in various commercial brewed coffees. Food Chem 106:217-221.

Jha S, Dick CW. 2010. Native bees mediate longdistance pollen dispersal in a shade coffee landscape mosaic. PNAS 31:13760-13764.

Jolliffe PA, Minjas AN, Runeckles VC. 1984. A reinterpretation of yield relation-ships in replacement series experiments. J Appl Ecol 21:227-243.

Lemes LN, Carvalho LB, Souza MC, Alves PLCA. 2010. Weed interference on coffee fruit production during a four-year investigation after planting. African J Agric Res 5:1138-1143.

Lopes SA, Marcussi S, Torres SCZ, Souza V, Fagan C, França SC, Fernandes NG, Lopes JRS. 2003. Weeds as alternative hosts of the citrus, coffee, and plum strains of Xylella fastidiosa in Brazil. Plant Dis 87:544-549.

Loreto F, Bongi G. 1989. Combined low temperaturehigh light effects on gas exchange properties of jojoba leaves. Plant Physiol 91:1580-1585. 
Marana JP, Miglioranza E, Fonseca EP, Kainuma RH. 2008. Seedling quality in coffee grown in container. Ci Rural 38:39-45.

Marcolini LW, Alves PLCA, Dias TCS, Parreira MC. 2009. Effect of the density and of the distance of Brachiaria decumbens Staff on the initial growth of Coffea arabica L. seedlings. Coffee Sci 4:11-15.

Merotto Júnior A, Fischer AJ, Vidal RA. 2009. Perspectives for using light quality knowledge as an advanced ecophysiological weed management tool. Planta Daninha 27:407-419.

Naidu MM, Sulochanamma G, Sampathu SR, Srinivas P. 2008. Studies on extraction and antioxidant potential of green coffee. Food Chem 107:377-384.

Nascimento EA, Oliveira LEM, Castro EM, Delú Filho N, Mesquita AC, Vieira CV. 2006. Morphophysiological alternations in leaves of Coffea arabica L. plants in consort with Hevea brasiliensis Muell. Arg. Ci Rural 36:852-857.

Nishio JN, Sun J, Vogelmann TC. Photoinhibition and the light environment within leaves. In: Baker NR, Bowyer JR. (eds.). Photoinhibition of photosynthesis. Oxford: BIOS Scientific Publishers, 1994. pp.1-24.

Radosevich SR, Holt J, Guersa C. 1997. Weed ecology: implication for managements. New York: John Wiley \& Sons, 1997. 589p.

Ronchi CP, Terra AA, Silva AA. 2007. Growth and nutrient concentration in coffee root system under weed species competition. Planta Daninha 25:679687.

Sharkey TD, Raschke K. 1981. Effect of light quality on stomatal opening in leaves of Xanthium strumarium L. Plant Physiol 68:1170-1174.

Silva AA, Ronchi CP. 2003. Advances in weed control researches in coffee plantation. In: Zambolim L. (ed.). Integrated coffee production. Viçosa: UFV, 2003. pp.103-132.

Silva FM, Souza ZM, Figueiredo CAP, Marques Júnior. J, Machado RV. 2007. Spatial variability of chemical attributes and coffee productivity in two harvests. $\mathrm{Ci}$ Rural 37:401-407.

Taiz L, Zeiger E. 2006. Plant Physiology. 4 ed. Sinauer Associates, Sunderland, MA. 700p.

Received on January 26, 2012.

Accepted on February 27, 2012.

Online published on March 01, 2012. 